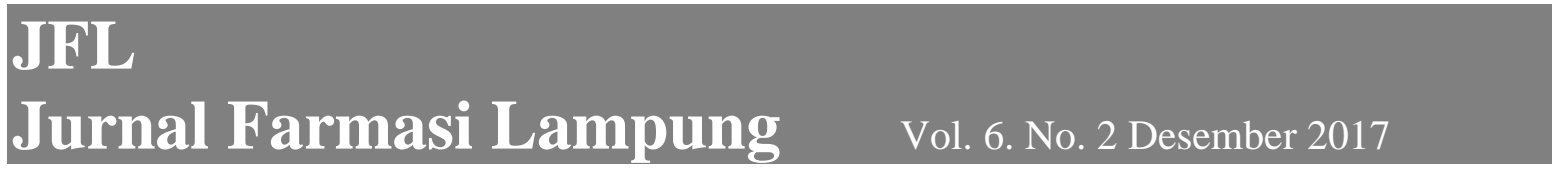

\title{
EKSTRAK DAUN KATUK (Sauropus androgynus (L) Merr) SEBAGAI ANTIBAKTERI TERHADAP Propionibacterium acnes dan Staphylococcus epidermidis
}

\author{
Antibacterial Activity of (Sauropus androgynus (L) Merr) Extract Againts \\ Propionibacterium acnes and Staphylococcus Epidermidis \\ Yuli Wahyu Tri Mulyani, Dadan Hidayat, Isbiyantoro, Yeny Fatimah \\ Farmasi-Universitas Tulang Bawang Lampung \\ Email : yuliwahyu.bio@gmail.com
}

\begin{abstract}
Katuk is one of the most common plant species in Indonesia which is known by the community to treat the disease, especially the leaf part can be used as a milk mat. katuk leaf (Sauropus androgynus (L) Merr) also contains saponin, flavonoid and tannin Inhibits the growth of bacteria one of the bacteria that cause acne bacteria P. acnes and S. epidermidis. The aim of this research is to know the antibacterial inhibition effect of katuk leaf extract to growth of $P$. acnes and S. epidermidis using Cup-plate or pit diffusion method with concentration $20 \%, 40 \%, 60 \%, 80 \%$ and $100 \%$. Clindamycin is used as a positive control and aquades as a negative control. The leaves of katuk extracted with $70 \%$ ethanol solvent showed no antibacterial activity against $P$. acnes bacteria while against $S$. epidermidis bacteria showed antibacterial activity. The highest antibacterial activity at 100\% concentration with $18.17 \mathrm{~mm}$ zone diameter belong to the category of inhibitory resistance of medium growth and the lowest concentration at concentration of $40 \%$ with $16.68 \mathrm{~mm}$ inhibitory zone diameter belong to the weak growth inhibitory response category. The minimum inhibitory concentrations produced in S. epidermidis bacteria were $39 \%-36 \%$.
\end{abstract}

\section{Keywords : Sauropus androgynus, Propionibacterium acnes, Staphilococcus epidermidis, Minimal Inhibitory Concentration.}

\begin{abstract}
Abstrak
Katuk merupakan salah satu jenis tanaman yang sering dijumpai di Indonesia yang telah diketahui oleh masyarakat dapat mengobati penyakit, terutama bagian daunnya dapat digunakan sebagai pelancar air susu ibu. Daun katuk (Sauropus androgynus (L) Merr) juga mengandung senyawa saponin, flavonoid, dan tannin yang mampu menghambat pertumbuhan bakteri salah satunya bakteri penyebab jerawat yaitu bakteri $P$. acnes dan $S$. epidermidis. Penelitian ini bertujuan untuk mengetahui daya hambat antibakteri ekstrak daun katuk terhadap pertumbuhan $P$. acnes dan $S$. epidermidis dengan menggunakan metode difusi lubang (Cup-plate) atau sumuran dengan konsentrasi $20 \%, 40 \%, 60 \%, 80 \%$ dan $100 \%$. Klindamisin digunakan sebagai kontrol positif dan aquades sebagai kontrol negatif. Daun katuk yang telah diekstraksi dengan pelarut etanol $70 \%$ menunjukkan tidak ada aktivitas antibakteri terhadap bakteri $P$. acnes sedangkan terhadap bakteri $S$. epidermidis menunjukan adanya aktivitas antibakteri. Aktivitas antibakteri tertinggi pada konsentrasi $100 \%$ dengan diameter zona $18,17 \mathrm{~mm}$ tergolong dalam kategori respon hambat pertumbuhan sedang dan konsentrasi terendah pada konsentrasi $40 \%$ dengan
\end{abstract}




\section{JFL \\ Jurnal Farmasi Lampung Vol. 6. No. 2 Desember 2017}

diameter zona hambat $16,68 \mathrm{~mm}$ tergolong dalam kategori respon hambat pertumbuhan lemah. Konsentrasi hambat minimum yang dihasilkan pada bakteri S. epidermidis 39\% - 36 $\%$.

Kata kunci : Sauropus androgynus, Propionibacterium, Staphylococcus epidermidis acnes, Konsentrasi Hambat Minimum

\section{PENDAHULUAN}

Penyakit infeksi masih merupakan jenis penyakit yang paling banyak diderita oleh penduduk di negara berkembang, termasuk Indonesia. Salah satu penyebab penyakit infeksi adalah bakteri. Bakteri merupakan mikroorganisme yang tidak dapat dilihat dengan mata telanjang, tetapi hanya dapat dilihat dengan bantuan mikroskop [1].

Kulit adalah tempat yang tidak ramah bagi kebanyakan mikroorganisme karena sekresi kulit bersifat asam dan sebagian besar kulit kelembabannya sangat rendah dan beberapa mikroba yang berkolonisasi pada kulit dapat menyebabkan penyakit. Penyakit infeksi pada kulit yang disebabkan oleh bakteri adalah jerawat, eksim, bisul, impetigo, campak, kudis dan kurap [2].

Jerawat dapat disebabkan oleh bakteri Propionibacterium acnes dan Staphylococcus epidermidis. Bakteri ini tidak patogen pada kondisi normal, tetapi bila terjadi perubahan kondisi kulit, maka bakteri tersebut berubah menjadi invasive [3].

Penelitian lain melaporkan efektivitas ekstrak daun katuk dalam menghambat pertumbuhan bakteri Staphylococcus aureus secara invitro dengan menggunakan metode sumuran menunjukkan bahwa ekstrak daun katuk dapat menghambat bakteri Stapylococcus aureus pada konsentrasi $60 \%$ sampai $100 \%$ [4], hal ini menunjukan semakin besar konsentrasi maka semakin banyak bakteri yang dapat dihambat

\section{METODE PENELITIAN}

\section{Tempat dan Waktu penelitian}

Penelitian ini dilaksanakan di Laboratorium universitas lampung, dan Laboratorium Kesehatan Daerah Bandar Lampung.

\section{Alat dan Bahan}

Alat yang akan digunakan pada penelitian ini adalah erlemeyer, cawan petri, jarum ose, bunsen, tabung reaksi, rak tabung reaksi, erlenmeyer, autoklaf, gelas ukur, gelas piala, pipet tetes, pinset, timbangan, almari pendingin, rotary evaporator, oven, inkubator, mikropipet, jangka sorong, yellow tape.

Bahan yang digunakan antara lain daun katuk, bakteri uji Propionibacterium acnes dan Staphylococcus epidermidis, alumunium foil, media nutrient agar $(N A)$, media nutrient broth $(N B)$, aquades, kain fanel, kertas label, etanol $70 \%$, antibiotik klindamisin.

\section{Pembuatan Ekstrak Daun katuk}

Simplisia daun katuk sebanyak 100 gram dimaserasi dengan cara dimasukkan dalam wadah berwarna gelap, kemudian 
direndam dengan larutan etanol $70 \%$ sampai simplisia terendam, ditutup dengan aluminium foil, dengan mengganti pelarut setiap $1 \times 24$ jam, sampel yang direndam tersebut disaring menggunakan kertas saring menghasilkan maserat dan ampas, maserat dievaporasi menggunakan rotary evaporator. Proses maserasi dilakukan sebanyak delapan kali dengan etanol $70 \%$ dengan mengganti pelarut $1 \times 24$ jam.

\section{Pembuatan Suspensi Bakteri}

Biakan murni yang telah diperbanyak dalam media miring NA yang telah diinkubasi selama 24 jam pada suhu 37 ${ }^{\circ} \mathrm{C}$, biakan diaambil 1 ose kemudian disuspensikan kedalam $\mathrm{NaCl}$ 0,86 \% dan diukur kekeruhannya dengan nephelometer dengan standar 0,5 Mc Farland yang setara dengan $1,5 \times 10^{8}$ (CFU) Colony Formation Unit.

\section{Uji Daya Antibakteri}

Menyiapkan cawan petri yang berisi media NA dihomogenkan dan dibiarkan membeku, kemudian masing-masing suspensi bakteri uji digoreskan ke dalam cawan yang telah berisi media NA yang telah memadat, beberapa lubang dibuat pada agar nutrien dengan menggunakan yellow tape dengan berdiameter $5 \mathrm{~mm}$.

Sebanyak $50 \mu \mathrm{L}$ bahan uji dengan konsentrasi $20 \%, 40 \%, 60 \%, 80 \%, 100 \%$ dan antibiotik klindamisin sebagai kontrol (positif), aquades kontrol (negatif) dimasukkan dalam lubang sumuran.

Semua cawan petri di inkubasi dalam inkubator pada suhu $37^{\circ} \mathrm{C}$ selama $18-24$ jam. Diameter hambat yang terbentuk di sekitar lubang diamati..

\section{Uji Konsentrasi Hambat Minimum}

Untuk pengujian daya hambat minimum siapkan beberapa tabung reaksi yang berisi $1,9 \mathrm{ml}$ NB yang mengandung larutan uji dengan variasi dosis dari konsentrasi terkecil yang memiliki daya antibakteri sampai dosis yang tidak memberikan daya hambat ditambah 0,1 $\mathrm{ml}$ suspensi bakteri Propionibacterium acnes dan Staphylococcus epidermidis Selain itu disiapkan 3 tabung reaksi sebagai :

Kontrol media : Berisi $2 \mathrm{ml}$ media NB

Kontrol Larutan Uji : Berisi media NB 1,8 $\mathrm{ml}+0,2$ larutan uji dengan konsentrasi $100 \%$

Kontrol Bakteri : Berisi 1,9 ml media NB + 0,1 suspensi bakteri.

Masing-masing tabung di inkubasi selama 24 jam. Pengamatan dilakukan dengan membandingkan kekeruhan media. Larutan uji dengan agen antimikroba pada kadar terkecil yang terlihat jernih tanpa ada nya pertumbuhan mikroba ditetapkan sebagai KHM. Larutan yang ditetapkan sebagai KHM tersebut selanjutnya dikultur ulang pada media tanpa penambahan mikroba uji ataupun agen mikroba, dan diinkubasi selama 18-24 jam. Media yang terlihat tidak ada pertumbuhan mikroba ditetapkan sebagai konsentrasi bunuh minimum atau KBM [5]. 


\section{HASIL DAN PEMBAHASAN}

\section{Hasil Uji Daya Antibakteri Bakteri Propionibacterium acnes}

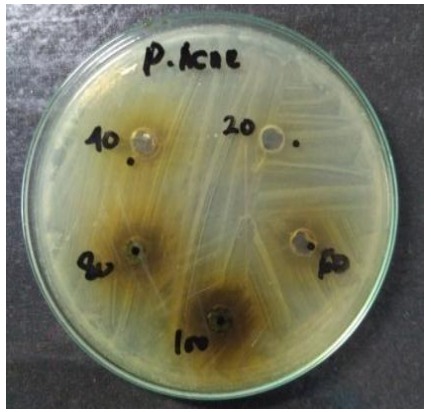

Gambar 1. Hasil uji daya antibakteri ekstrak daun katukdengan konsentrasi $20 \%, 40 \%, 60 \%, 80 \%$,dan 100\% terhadap bakteri Propionibacterium acnes.

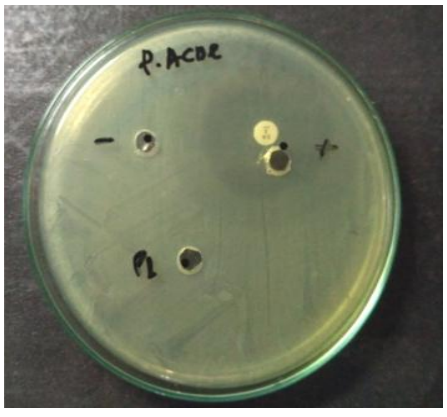

Gambar 2. Hasil kontrol positif, kontrol negatif dan pelarut etanol $70 \%$.

Hasil uji daya antibakteri ekstrak daun katuk terhadap bakteri Propionibacterium acnes tidak menunjukan adanya daya hambat, ditandai dengan tidak adanya daerah jernih disekitar lubang sumuran pada masing-masing konsentrasi dibandingkan luas zona hambat yang dihasilkan kontrol positif.

Hal ini dapat dikarenakan bakteri mempunyai sifat dan ketahanan yang berbeda-beda terhadap suatu antibakteri walaupun bakteri tersebut termasuk dalam satu golongan yang sama yaitu merupakan golongan bakteri Gram positif. Bakteri Propionibacterium acnes tidak dapat menghasilkan endospora mempunyai bentuk batang yang berkoloni membentuk rantai dan tidak dapat hidup tanpa adanya oksigen atau aerob sedangkan Staphylococcus epidermidis berbentuk bulat berkoloni membentuk anggur dan dapat hidup dengan atau tanpa adanya oksigen atau anaerob fakultatif [8].

Berdasarkan penelitian yang dilakukan ekstrak daun katuk dapat menghambat bakteri Staphylococus aureus pada konsentrasi $60 \%$ dengan diameter zona $10 \mathrm{~mm}$ dan konsentrasi $100 \%$ diameter zonna hambat $13 \mathrm{~mm}$ hal ini membuktikan bahwa senyawa yang tedapat pada daun katuk dapat menghambat atau membunuh bakteri dan hal ini kemungkinan bahwa hasil uji antibakteri ekstrak daun katuk terhadap bakteri Propionibacterium acnes tidak dapat menghambat disebabkan karena adanya perbedaan sifat dari bakteri Propionibacterium acnes dan Staphilococcus epidermidis [10].

Hasil uji daya antibakteri ekstrak daun katuk tidak menunjukan adanya daya hambat terhadap bakteri Propionibacterium acnes dan Staphylococcus epidermidis maka penentuan nilai KHM (konsentrasi hambat minimum), KBM (konsentrasi bunuh minimum) dan analisis data untuk bakteri Propionibacterium acnes tidak dilanjutkan. 


\section{Hasil Uji Daya Bakteri Staphylococcus epidermidis}

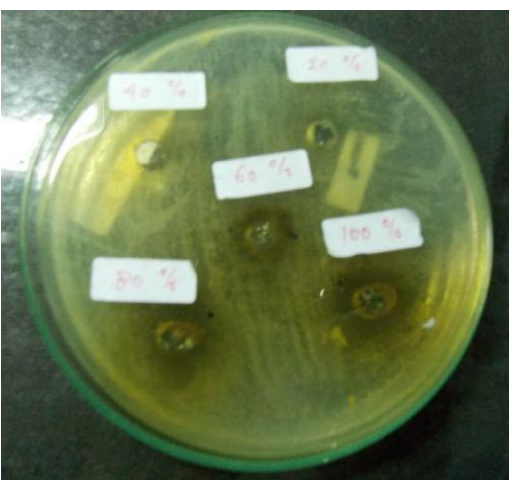

Gambar 3. Hasil uji daya antibakteri ekstrak daun katuk dengan konsentrasi $20 \%, 40 \%, 60 \%, 80 \%$,dan $100 \%$ terhadap bakteri Staphylococcus epidermidis.

Hasil uji daya antibakteri ekstrak daun katuk terhadap Staphylococcus epidermidis dengan menggunakan metode sumuran dan menggunkan media NA yang digunakan dalam uji antibakteri,

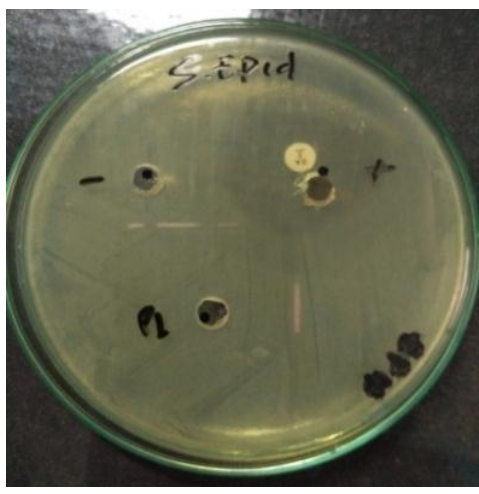

Gambar 4. Hasil kontrol positif, kontrol negatif dan pelarut etanol $70 \%$.

dan menggunakan media NA yang digunakan dalam uji antibakteri, menunjukan bahwa ekstrak daun katuk mempunyai daya hambat terhadap bakteri Staphylococcus epidermidis.

Tabel 1. Diameter zona hambat ekstrak daun katuk terhadap bakteri Staphylococcus epidermidis.

\begin{tabular}{|c|c|c|c|c|c|c|c|c|}
\hline \multirow[t]{2}{*}{$\begin{array}{c}\text { Sampel } \\
\text { Uji }\end{array}$} & \multicolumn{5}{|c|}{$\begin{array}{c}\text { Ulangan Perlakuan } \\
(\mathrm{mm})\end{array}$} & \multirow{2}{*}{$\begin{array}{c}\text { Diameter } \\
\text { Zona } \\
\text { Hambat } \\
(\mathrm{mm})\end{array}$} & \multirow{2}{*}{$\begin{array}{l}\text { Rata-rata } \\
\text { Zona } \\
\text { Hambat } \\
(\mathrm{mm})\end{array}$} & \multirow[t]{2}{*}{$\begin{array}{l}\text { Mann } \\
\text { Withney }\end{array}$} \\
\hline & 1 & 2 & 3 & 4 & 5 & & & \\
\hline K - & 0 & 0 & 0 & 0 & 0 & 0 & 0.00 & A \\
\hline $\mathrm{K}+$ & 20.1 & 20.15 & 20 & 20.02 & 20 & 100.27 & 20.05 & $E$ \\
\hline K 20\% & 0 & 0 & 0 & 0 & 0 & 0 & 0.00 & A \\
\hline K 40\% & 17.06 & 17.43 & 17 & 16 & 17.4 & 84.89 & 16.98 & $B$ \\
\hline K 60\% & 17.4 & 17.13 & 17.22 & 16.5 & 17.55 & 85.8 & 17.16 & B \\
\hline K 80\% & 17.99 & 17.65 & 17.66 & 17.4 & 17.75 & 88.45 & 17.69 & C \\
\hline K 100\% & 18.09 & 18.63 & 18 & 18.02 & 18.1 & 90.84 & 18.17 & $\mathrm{D}$ \\
\hline
\end{tabular}

Keterangan :

$\mathrm{K}(-) \quad$ : Menggunakan aquades.

$\mathrm{K}(+) \quad$ : Menggunakan antibiotik klindamicyn.

K 20 : Ekstrak daun katuk dengan konsentrasi

K 40\% : Ekstrak daun katuk dengan konsentrasi 40\%

K 60\% : Ekstrak daun katuk dengan konsentrasi $60 \%$ 
K 80\% : Ekstrak daun katuk dengan konsentrasi $80 \%$

K 100\% : Ekstrak daun katuk dengan konsentrasi $100 \%$

Mann Withney

- Huruf yang sama menyatakan tidak berbeda nyata

- Huruf yang berbeda menyatakan terdapat perbedaan nyata

Berdasarkan data pada Tabel 1 menunjukkan bahwa beberapa konsentrasi dari ekstrak daun katuk memiliki daya hambat terhadap pertumbuhan bakteri Staphylococcus epidermidis.

Pada konsentrasi 100\%, 80\%, 60\%, 40\% menunjukkan adanya zona hambat dengan diameter yang berbeda- beda pada setiap konsentrasi sedangkan pada konsentrasi $20 \%$ tidak menunjukan adanya zona hambat. Diameter zona hambat terkecil pada konsentrasi $40 \%$ $16,98 \mathrm{~mm}$ dan zona hambat terbesar pada konsentrasi $100 \%$ dengan diameter zona hambat $18,17 \mathrm{~mm}$.

Hal ini menunjukan ekstrak daun katuk terhadap bakteri Staphylococcus epidermidis mempunyai keefektifan dalam menghambat bakteri Staphylococus epidermidis. Pada hasil rata-rata menunjukan bahwa semakin tinggi konsentrasi ekstrak daun katuk maka diameter zona hambat semakin besar [7]. Konsentrasi terbesar menghasilkan zona hambat hampir mendekati zona hambat yang dihasilkan kontrol positif, zona hambat yang dihasilkan kontrol positif mempunyai respon hambatan pertumbuhan dalam ukuran kuat sedangkan pada konsentrasi terbesar yaitu $100 \%$ mempunyai respon pertumbuhan dalam ukuran sedang. Dapat dilihat pada Tabel 2.

Tabel 2. Respon Hambatan Pertumbuhan

\begin{tabular}{c|c}
\hline $\begin{array}{c}\text { Diameter } \\
\text { Zona Hambat }\end{array}$ & $\begin{array}{c}\text { Respon Hambatan } \\
\text { Pertumbuhan }\end{array}$ \\
\hline$>20 \mathrm{~mm}$ & Kuat \\
\hline $16-19 \mathrm{~mm}$ & Sedang \\
\hline $10-15 \mathrm{~mm}$ & Lemah \\
\hline$>10 \mathrm{~mm}$ & Sangat Lemah \\
\hline
\end{tabular}

Setelah diperoleh rata-rata zona hambat dilakukan analisis data dengan uji homogenitas secara statistik. Hasil dari uji homogenitas diperoleh data yang tidak homogen, dimana nilai KK (Koefesien Keragaman) lebih kecil dari pada 0,05. Sehingga tidak memenuhi syarat untuk dianalisis sidik ragam. 
Hasil tersebut menunjukkan termasuk data non-parametrik sehingga untuk analisis data menggunakan uji kruskalwallis. Uji ini dilakukan untuk melihat adanya perbedaan zona hambat secara signifikan atau antara kelompok kontrol negatif, sampel dan kontrol positif.

Hasil uji kruskal-wallis pada bakteri diperoleh nilai Asymp sig 0,000 yaitu $p<0.05$ yang menunjukkan bahwa zona hambat dari semua kelompok memiliki perbedaan yang signifikan, kemudian dilanjutkan uji mann withney.

Setelah dilakukan uji lanjut menggunakan uji mann withney hasilnya menunjukan bahwa ekstrak daun katuk terhadap bakteri bakteri Sthaphylococcus epidermidis pada K (-) dan K $20 \%$, tidak berbeda nyata, K $40 \%$ dan $\mathrm{K} 60 \%$ tidak berbeda nyata sedangkan $\mathrm{K} 60 \%$, K $80 \%$, K 100\% dan $\mathrm{K}+$ berbeda nyata. Dapat dilihat pada Tabel 2.

Uji skrining fitokimia yang dilakukan daun katuk positif mengandung senyawa golongan alkaloid, saponin, tanin, polifenol, dan flavonoid yang dapat menghambat atau membunuh bakteri [9].

Senyawa flavonoid memiliki aktivitas antibakteri dengan cara mengikat asam amino neofilik pada protein dan inaktivasi enzim, senyawa saponin memiliki aktivitas dengan cara menghambat atau membunuh bakteri dengan cara penurunan tegangan permukaan sel dan menyebabkan sel lisis sedangan senyawa tanin bekerja dengan mengikat dinding protein sehingga pembentukan dinding bakteri terhambat [1].

Berdasarkan penelitian yang dilakukan ekstrak daun katuk dapat menghambat bakteri Staphylococus aureus pada konsentrasi $60 \%$ dengan diameter zona $10 \mathrm{~mm}$ dan konsentrasi $100 \%$ diameter zonna hambat $13 \mathrm{~mm}$ hal ini membuktikan bahwa senyawa yang tedapat pada daun katuk dapat menghambat atau membunuh bakteri [4].

Bakteri Staphylococcus epidermidis juga telah dilakukan penelitian dengan menggunakan ekstrak lain yaitu daun sirih hijau, bakteri Staphylococcus epidermidis yang merupakan bakteri penyebab jerawat pada penelitian ini ekstrak daun sirih hijau mempunyai aktivitas daya hambat terhadap bakteri Staphilococcud epidermidis pada konsentrasi 3\% dengan diameter zona hambat $9,8 \mathrm{~mm}$ dan $5 \%$ dengan diameter zona hambat $15 \mathrm{~mm}$ [7].

Pada penelitian ini menggunakan antibiotik klindamisin sebagai kontrol positif yang dapat bekerja sebagai bakteriostatik maupun bakterisid tergantung pada konsentrasi obat, tempat infeksi dan organisme penyebab infeksi.

Berdasarkan spektrumnya antibiotik ini termasuk dalam golongan antibiotik berspektrum sempit atau mempunyai aktivitas sempit yang bekerja hanya terhadap bakteri gram positif saja [5]. 


\section{Konsentrasi Hambat Minimum dan Konsentrasi Bunuh Minimum}

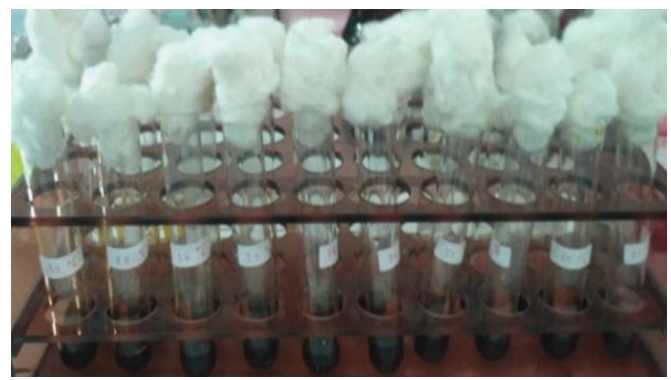

Gambar 5. Hasil uji KHM

Uji konsentrasi hambat minimu (KHM) dilakukan pada beberapa konsentrasi yaitu dari konsentrasi 39\% - 20\%. Pada hasil uji KHM tidak dapat diamati kekeruhannya pada masing-masing konsentrasi, hal ini disebabkan warna ekstrak dari hasil evaporasi berwarna pekat sehingga perlu digoreskan kembali pada media NA dari masing masing konsentrasi ekstrak daun katuk untuk melihat hasil dari KHM. Dapat dilihat pada Gambar 5.

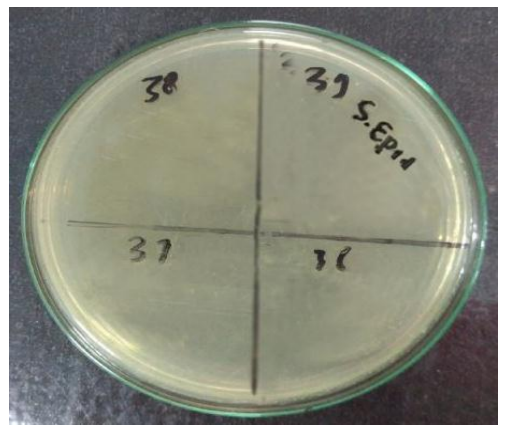

Gambar 6. Hasil uji KHM

Setelah konsentrasi 39\% - 20\% ditanam pada media NA hasil uji KHM ekstrak daun katuk terhadap pertumbuhan bakteri Staphylococcus epidermidis menunjukan bahwa pada konsentrasi $39 \%-36 \%$ tidak ada pertumbuhan sedangkan pada konsentrasi 35\% -21\% ada pertumbuhan bakteri Staphylococcus epidermidis, dapat dilihat pada Gambar 6.

Maka dapat disimpulkan konsentrasi hambat minimum (KHM) pada penelitian ini yaitu pada konsentrasi 39\% - 36\%.

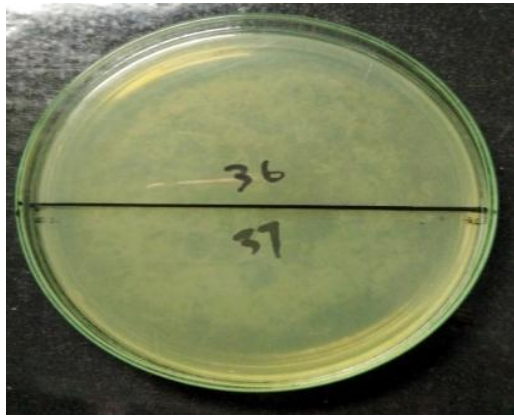

Gambar 7. Uji KBM

Hasil uji KHM menunjukan bahwa pada konsentrasi 39\% - 36\% menunjukan tidak ada pertumbuhan bakteri Staphylococcus epidermidis kemudian untuk konsentrasi yang tidak ada pertumbuhan bakteri digoreskan terhadap media NA untuk menentukan KBM (Konsentrasi Bunuh Minimum) dan melihat adanya pertumbuhan bakteri atau tidak ada pertumbuhan bakteri, uji KBM dilakukan untuk mengetahui apakah ekstrak daun katuk apakah bersifat bakteriostatik atau bakterisid, hasil uji KBM menunjukan bahwa ekstrak daun katuk bersifat bakterisid dengan tidak adanya pertumbuhan bakteri, dapat dilihat pada Gambar 7 .

Berdasarkan beberapa pembahasan maka dapat disimpulkan bahwa ekstrak daun katuk (Sauropus androgynus (L) Merr) dapat digunakan sebagai alternatif pengobatan jerawat yang disebabkan bakteri Staphylococcus epidermidis. 


\section{KESIMPULAN DAN SARAN}

\section{Kesimpulan}

Berdasarkan hasil penelitian yang telah dilakukan dapat disimpulkan bahwa daun katuk tidak memiliki daya antibakteri terhadap bakteri Propionibacterium acnes dan ekstrak daun katuk mempunyai daya antibakteri terhadap bakteri Staphylococcus epidermidis pada konsentrasi $40 \%$, $60 \%, 80 \%$ hingga konsentrasi tertinggi $100 \%$ dengan diameter zona hambat

$18,17 \mathrm{~mm}$ dan konsentrasi terendah $40 \%$ berdiameter zona hambat 16,98 $\mathrm{mm}$.

\section{Saran}

Perlu dilakukan penelitian lebih lanjut dengan menggunakan metode yang berbeda sehingga dapat diketahui konsentrasi paling optimal dari ekstrak daun katuk (Sauropus androgynus (L) Merr).

\section{DAFTAR PUSTAKA}

[1] Deby A. Mpila. Fatimawali. Weny Wiyono. 2012. Uji Aktivitas Antibakteri Ekstrak Etanol Daun Mayana (Coleus atropurpureus [L] Benth) Terhadap Staphylococcus aureus, Escherichia coli dan Pseudomonas aeruginosa Secara In-vitro. Jurnal Penelitian. vol 1.

[2]. Ayu M. Penyakit Kulit. 2014. Yogyakarta: Pustaka Baru press.

[3] Jawetz M. Adelberg's. 2005. Mikrobiologi Kedokteran (Medical Microbiology). Jakarta: Salemba Medika.

[4] Siti F. Yuliani P. Aris M. 2014. Efektivitas Ekstrak Daun Katuk (Sauropus Androgynus L) Dalam Menghambat Pertumbuhan Bakteri Staphylococcus Aureus. Jurnal Penelitian Stikes Guna
Bangsa.

[5] Pratiwi S.T. 2008. Mikrobiologi Farmasi. Yogyakarta: Eirlangga.

[6] Sukmawati A.M.T. 2010. Uji Aktivitas Antibakteri Ekstrak Etil Aseta Kelopak Rosella (Hibiscus Sabdariffa Linn.) Terhadap Propionibacterium Acne, Escherichia Coli, dan Staphylococcus aureus serta Uji Bioautografi. Skripsi. Fakultas Farmasi. Universitas Muhamadiyah Surakarta.

[7] Julianri. Kursia S. S.lembang. 2016. Uji Aktivitas Antibakteri Etilasetat Daun Sirih Hijau (Piper betle L) Terhadap Bakteri Staphilococcus epidermidis. Jurnal Penelitian Sekolah Tinggi IImu Farmasi Makassar. vol 3.

[8] Mulyani Y. Bachtiar E. A Untung. 2013. Peranan Senyawa Metabolit Skunder Tumbuhan Magrove Terhadap Infeksi Bakteri Aeromonas hydrophila pada ikan mas (cyprinus carpio L). Jurnal Akuantika. vol 4:1-9.

[9] Susanti, N.M.P. Budiman, I.N.A. Warditiani NK. 2014. Skrining Fitokimia Ekstrak Etanol 90\% Daun Katuk (Sauropus androgynus (L.) Merr.). Jurnal Farmasi Fakultas Matematika Dan IImu Pengetahuan Alam Universitas Udayana. vol 1:3. 


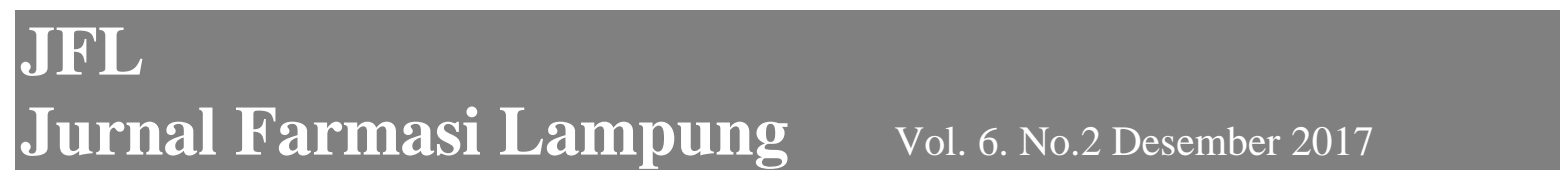

